\title{
Switch-Peptides: Design and Characterization of Controllable Super-Amyloid-Forming Host-Guest Peptides as Tools for Identifying Anti-Amyloid Agents
}

\author{
Marie-Stéphanie Camus, ${ }^{[b]}$ Sonia Dos Santos, ${ }^{[b]}$ Arunan Chandravarkar, $_{,}^{[b]}$ \\ Bhubaneswar Mandal, ${ }^{[b]}$ Adrian W. Schmid, ${ }^{[b]}$ Gabriele Tuchscherer, $^{[b]}$ Manfred Mutter, ${ }^{[b]}$ and \\ Hilal A. Lashuel*[a]
}

\begin{abstract}
Several amyloid-forming proteins are characterized by the presence of hydrophobic and highly amyloidogenic core sequences that play critical roles in the initiation and progression of amyloid fibril formation. Therefore targeting these sequences represents a viable strategy for identifying candidate molecules that could interfere with amyloid formation and toxicity of the parent proteins. However, the highly amyloidogenic and insoluble nature of these sequences has hampered efforts to develop highthroughput fibrillization assays. Here we describe the design and characterization of host-guest switch peptides that can be used for in vitro mechanistic and screening studies that are aimed at discovering aggregation inhibitors that target highly amyloidogenic sequences. These model systems are based on a host-guest system where the amyloidogenic sequence (guest peptide) is flanked by two $\beta$-sheet-promoting (Leu-Ser) $)_{n}$ oligomers as host sequences. Two host-guest peptides were prepared by using the
\end{abstract}

hydrophobic core of $A \beta$ comprising residues 14-24 (HQKLVFF$A E D V)$ as the guest peptide with switch elements inserted within (peptide 1) or at the $N$ and $C$ termini of the guest peptide (peptide 2). Both model peptides can be triggered to undergo rapid self-assembly and amyloid formation in a highly controllable manner and their fibrillization kinetics is tuneable by manipulating solution conditions (for example, peptide concentration and $p H)$. The fibrillization of both peptides reproduces many features of the full-length $A \beta$ peptides and can be inhibited by known inhibitors of $A \beta$ fibril formation. Our results suggest that this approach can be extended to other amyloid proteins and should facilitate the discovery of small-molecule aggregation inhibitors and the development of more efficacious anti-amyloid agents to treat and/or reverse the pathogenesis of neurodegenerative and systemic amyloid diseases.

\section{Introduction}

Protein misfolding and self-assembly into $\beta$-sheet-rich fibrillar structures "amyloid fibrils", is a pathological feature of several neurodegenerative diseases including Alzheimer's, Parkinson's, Huntington's, and prion diseases, ${ }^{[1]}$ for which only symptomatic treatments are available today. The pathology of Alzheimer's disease $(A D)$ is characterized by the presence of two different types of fibrillar protein aggregates: 1) extracellular amyloid plaques that are composed of fibrillar aggregates of amyloid $\beta$ $(A \beta)$ peptides (A $\beta 42$ and $A \beta 40)$ ) and 2) intracellular neurofibrillary tangles that are composed of fibrillar aggregates of the microtubule-associated protein, tau. ${ }^{[2]}$ Although the aggregation of $A \beta$ has been implicated as the primary trigger of neurodegeneration and cause of neurological deficits in memory impairment and cognitive function found in $A D_{1}^{[3]}$ the mechanisms by which this process contributes to neurodegeneration and disease phenotype as well as the nature of the toxic species remain poorly understood. ${ }^{[4]}$ Despite this gap in knowledge, increasing evidence from various disciplines indicates that interfering with protein misfolding and aggregation constitutes a viable therapeutic strategy to prevent and/or reverse the progression of these devastating diseases. Several therapeutic strategies aimed at reducing, inhibiting, and/or reversing amyloid formation have shown promising results in animal models of $A D$, and clinical trials are currently underway to evaluate their efficacy in humans. ${ }^{[4]}$ Thus, screening for inhibitors and modifiers of $A \beta$ aggregation and fibrillogenesis continues to attract great attention from academic, biotech, and pharmaceutical companies.

$A \beta$ is a 39-42-amino-acid peptide that exhibits a high propensity for spontaneous aggregation, particularly the more amyloidogenic form $A \beta 42$. The strong dependence of $A \beta$ aggregation on solution conditions and handling of the peptide during its synthesis and purification has resulted in variable and conflicting data concerning the mechanism that underlies $A \beta$ aggregation and toxicity in vitro. In addition, the high cost

\footnotetext{
[a] Prof. H. A. Lashuel

Brain Mind Institute (BMI), Ecole Polytechnique Fédérale de Lausanne (EPFL) 1015 Lausanne (Switzerland)

Fax: $(+41) 21-693-1780$

E-mail: hilal.lashuel@epfl.ch

[b] Dr. M.-S. Camus, Dr. S. Dos Santos, Dr. A. Chandravarkar, Dr. B. Mandal, Dr. A. W. Schmid, Dr. G. Tuchscherer, Prof. M. Mutter Institute of Chemical Sciences and Engineering (ISIC) Ecole Polytechnique Fédérale de Lausanne (EPFL) 1015 Lausanne (Switzerland)

Supporting information for this article is available on the WWW under http://www.chembiochem.org or from the author.
} 
of the full-length synthetic $A \beta$ peptides combined with the $a b$ sence of efficient recombinant expression systems for producing these peptides have limited the range of biophysical studies and high-throughput screening (HTS) efforts to identify inhibitors of $A \beta$ aggregation and toxicity.

Previously, we ${ }^{[5-8]}$ and others ${ }^{[9-12]}$ have shown that various steps along the amyloid formation pathway, including peptide/ protein misfolding, self-assembly, and amyloid formation and disassembly, can be triggered in a highly controllable manner through the incorporation of molecular switches into the amyloid-forming polypeptides, based on in situ intramolecular $\mathrm{O} \rightarrow$ $\mathrm{N}$ acyl migration. ${ }^{[5-16]}$ However, because of the special synthetic and purification skills required to prepare the full-length $A \beta$ switch-peptides, such peptides are not suitable for use in highthroughput screening assays. Therefore, the development of reliable model systems that are readily accessible and adaptable to automated HTS is of particular interest to understanding the mechanism of amyloid formation and facilitating the discovery of aggregation inhibitors of $A \beta$ and other amyloid-forming proteins.

Herein, we describe the preparation and characterization of affordable and synthetically accessible switch-peptides ${ }^{[5-8]}$ as model systems for understanding the molecular and structural basis of amyloid formation and to identify small-molecule inhibitors of $A \beta$ aggregation and toxicity. These model systems are based on a host-guest system where the hydrophobic core of $A \beta$, which comprises residues 14-24 (HQKLVFFAEDV), is flanked by two $\beta$-sheet-promoting (Leu-Ser) ${ }_{n}^{[18]}$ oligomers as host sequences. The host sequences serve the primary purpose of accelerating the fibrillization of the guest peptide.

To maintain the peptides in a monomeric random coil (r.c.) conformation, switch elements were strategically placed into the host-guest peptide to interfere with $\beta$-sheet formation and self-assembly until acyl migration is initiated with the appropriate triggers. To design a model peptide system that best reproduces the aggregation of the full-length $A \beta$ peptides with $t_{1 / 2}$ values for acyl migration and aggregation kinetics that are suitable for HTS, the number, position, and type of switch elements were varied. Two host-guest peptide systems were designed: one containing a single switch element at position 21 by replacing alanine 21 with serine (peptide 1 ) and a second peptide containing two switch elements at the $\mathrm{N}$ and $\mathrm{C}$ termini of the guest sequence $A \beta(14-24)$ (peptide 2; Figure 1). Peptide 2 represents a more general system that can be used when the guest sequence of interest lacks serine residues or when the insertion of a serine residue in the guest sequence is not desired. Furthermore, placing the switch elements outside the target sequence $(A \beta(14-24)$ in peptide 2$)$ serves two purposes; 1) it maintains the original sequence of the guest peptide; and 2) it provides sufficient time for the interaction between the small molecules and the guest sequence before fibrillization through activation of the host sequence. In the case of peptide 2, this strategy also allows the effect of introducing the switch element within $A \beta(14-24)$ on the aggregation and binding properties of this region to be determined.

The acyl migration, that is, restoring the regular backbone of the host-guest peptide, can be triggered enzymatically by addition of the enzyme dipeptidyl peptidase IV (DPPIV) in the case of peptide $\mathbf{1}$, or by adjusting the $\mathrm{pH}$ to 7.0 for peptide $\mathbf{2}$. Therefore, aggregation can be triggered by restoring the normal amide backbone of $A \beta(14-24$; peptide 1$)$ or $\beta$-sheetpromoting (Leu-Ser) $)_{n}$ oligomers (peptide 2). Upon acyl migration $\left(\mathrm{S}_{\text {off }} \rightarrow \mathrm{S}_{\text {on }}\right.$ ), the in statu nascendi (ISN) induction of conformational transitions from random-coil to $\beta$-sheet occurs very rapidly, and amyloid formation is completed within $30 \mathrm{~min}$ to $5 \mathrm{~h}$ depending on the concentration of the peptide and the triggering procedure. Such model host-guest switch peptides provide useful tools to characterize early folding and aggregation events during the fibrillization of $A \beta$-derived peptides and for HTS screening of $A \beta$ inhibitors and $\beta$-breakers; this bypasses the difficulties that are associated with the use of the native full-length peptides $A \beta 42$ and $A \beta 40$.

\section{Results}

Peptides 1 and $\mathbf{2}$ are disordered, but undergo rapid self-assembly and amyloid formation upon induction of $\mathrm{O} \rightarrow \mathrm{N}$ acyl migration. In the $S_{\text {off }}$ state, both peptides 1 and $\mathbf{2}$ remain monomeric and show $C D$ spectra that are consistent with random coil conformations (Figure 2A). The peptide's ability to undergo ISN conformational transitions from random-coil to $\beta$-sheet structures upon triggering of the switch elements was analyzed by using HPLC, circular dichroism (CD) spectroscopy, and transmission electron microscopy. Enzymatic triggering of peptide 1 $(50 \mu \mathrm{M})$ results in striking changes in the peptide's secondary structure, which shows a rapid conformational transition from random coil in the $S_{\text {off }}$ state, to a predominantly $\beta$-sheet structure in the $S_{\text {on }}$ state within 30 min (Figure $2 \mathrm{~B}$ ). In the absence of the trigger, formation of amyloid fibrils (Figure $2 \mathrm{C}$ ) was observed only at higher peptide concentrations $(>200 \mu \mathrm{M})$, and after several days of incubation at $37^{\circ} \mathrm{C}$ due to slow temperature-induced ester hydrolysis. These results demonstrate the ability of these peptide systems to form amyloid fibrils that resemble those that are formed by the full-length $A \beta 1-40$ and 1-42 peptides.

The $\mathrm{O} \rightarrow \mathrm{N}$ acyl migration in peptide $\mathbf{1}$ is triggered by adding the enzyme DPPIV (0.02 unit), whereas for peptide 2 the conversion from the $S_{\text {off }}$ to $S_{\text {on }}$ state is triggered by adjusting the $\mathrm{pH}$ to 7.4 by adding $10 \%$ PBS ( $30 \mathrm{~mm}, 150 \mathrm{~mm} \mathrm{NaCl}, \mathrm{pH} 7.4)$. Conversion from the $S_{\text {off }}$ to $S_{\text {on }}$ state in peptide 1 and peptide $\mathbf{2}$ is monitored by analytical RP-HPLC. In the case of peptide $\mathbf{1}$ $(400 \mu \mathrm{M})$, addition of DPPIV results in the appearance of two additional peaks with retention times of $15.7 \mathrm{~min}$ and $7.2 \mathrm{~min}$ (Figure $3 \mathrm{~A})$. The gradual decrease of the $\mathrm{S}_{\text {off }}$ peak $\left(t_{\mathrm{R}}=\right.$ $15.2 \mathrm{~min}$ ) and the appearance of a new peak with increased hydrophobicity at $t_{\mathrm{R}}=15.7 \mathrm{~min}$ corresponds to the conversion to the $S_{\text {on }}$ state of the peptide. The peak with $t_{R}=7.2$ min corresponds to the Arg-Pro dipeptide cleavage product (Figure $3 \mathrm{~A}$ ), as discerned by mass spectrometry (data not shown). In the case of peptide $\mathbf{2}$ (Figure $3 \mathrm{~B}$ ), upon $\mathrm{pH}$ triggering, we observed a relatively fast conversion from the $S_{\text {off }}\left(t_{R}=\right.$ $19.6 \mathrm{~min})$ to $S_{\text {on }}\left(t_{R}=20.3 \mathrm{~min}\right)$ state with a half life for migration of approximately $t_{1 / 2} \sim 25 \mathrm{~min}$, which is similar to peptide 1. The appearance and subsequent decrease of the $S_{\text {on }}$ peak 
$\mathbf{A} \beta$

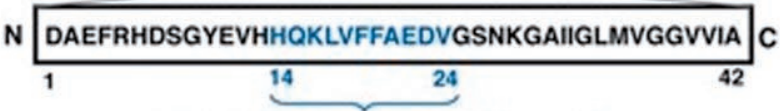

core sequence for fibril formation

Peptide 1

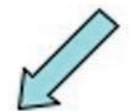

今 AC-SLSL-HOKLVFF(RP)S $S^{2} E D V \cdot S L G \cdot \mathrm{NH}_{2} \quad 1$

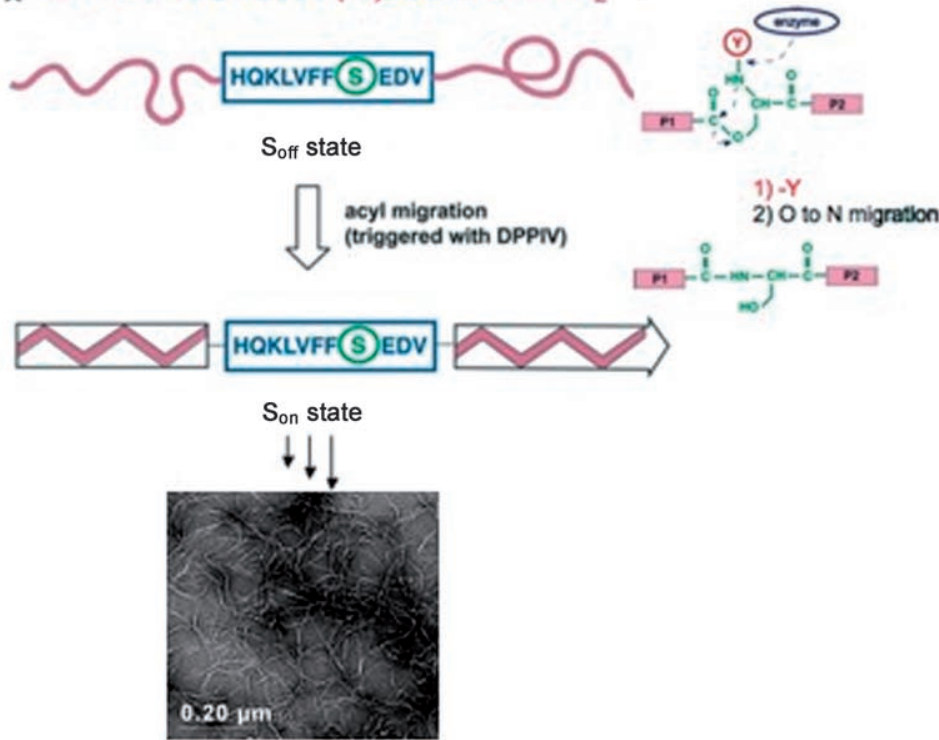

Peptide 2
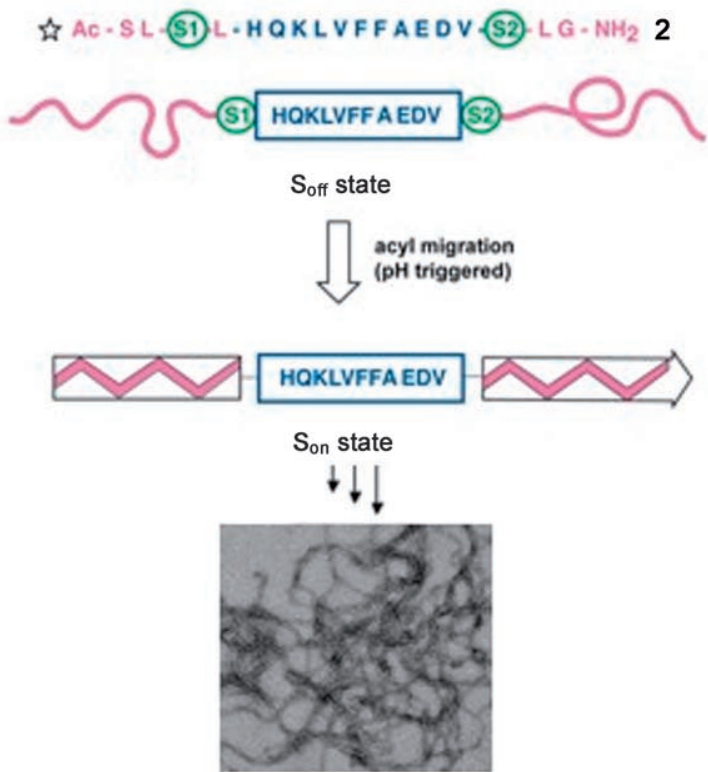

Figure 1. Design principles of host-guest switch-peptides that are derived from $A \beta$ : peptide 1, [Ser21] A $\beta(14-24)$, with a single switch at position 21 (left) and peptide 2, which contains two switch elements at the $\mathrm{N}$ and $\mathrm{C}$ termini of the guest peptide $A \beta(14-24)$. In the $\mathrm{S}_{\text {off }}$ state, peptides 1 and $\mathbf{2}$ are designed to adopt a random coil conformation. After addition of the enzyme DPPIV (peptide 1) or adjusting the pH to physiological conditions (pH 7.0, peptide 2), spontaneous acyl migration occurs, which results in peptide folding and initiation of amyloid formation.
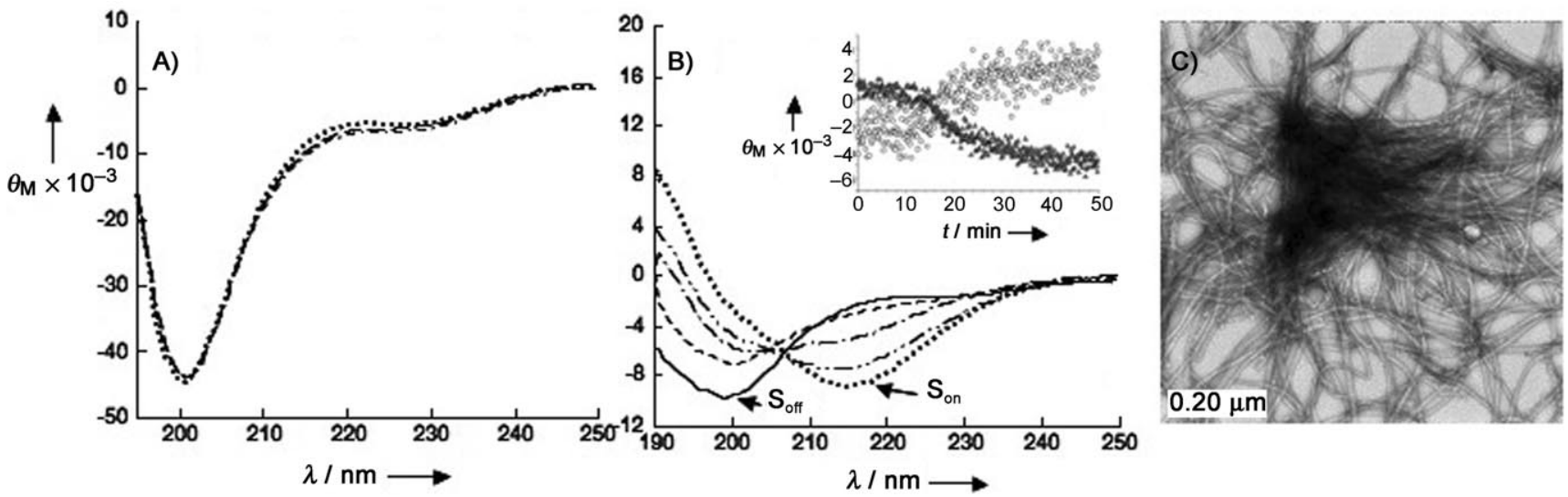

Figure 2. A) CD spectra of peptide $1(200 \mu \mathrm{m})$ in the $\mathrm{S}_{\text {off }}$ state in Tris buffer $(500 \mu \mathrm{M}$ and $2.5 \mathrm{~mm} \mathrm{NaCl}, \mathrm{pH} 8)$ plus $10 \% \mathrm{MeOH}$ at $37{ }^{\circ} \mathrm{C}$. In the $\mathrm{S}_{\text {off }}$ state, peptide 1 remains in a random coil conformation (blue) and no transition to a $\beta$-sheet is observed even after incubation for three days (red). B) Peptide 1 undergoes rapid transition from a random coil ( $t=0$, green) to a $\beta$-sheet conformation ( $t=30 \mathrm{~min}$, pink) upon triggering acyl migration at $37^{\circ} \mathrm{C}$ in Tris buffer, $\mathrm{pH} 8$, plus $10 \% \mathrm{MeOH}$ and $2.5 \mathrm{~nm} \mathrm{NaCl}$ ([peptide] $=50 \mu \mathrm{M}$ ). Inset: Increase in $\beta$-sheet formation over time as monitored by an increasing $\beta$-sheet signal at $218 \mathrm{~nm}(\bullet$ ), and a decrease in the random coil signal at $195 \mathrm{~nm}$ ( blue dots). C) Amyloid fibril formation of peptide 1 ( $\mathrm{S}_{\mathrm{off}}$ state) at a concentration of $200 \mu \mathrm{M}$ after seven days of incubation at $37^{\circ} \mathrm{C}$. 


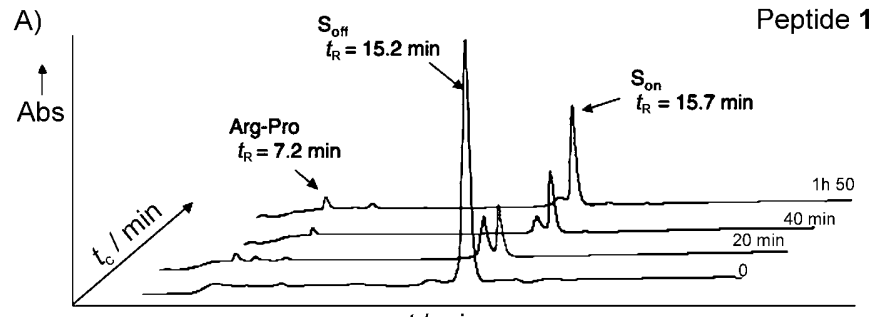

B)

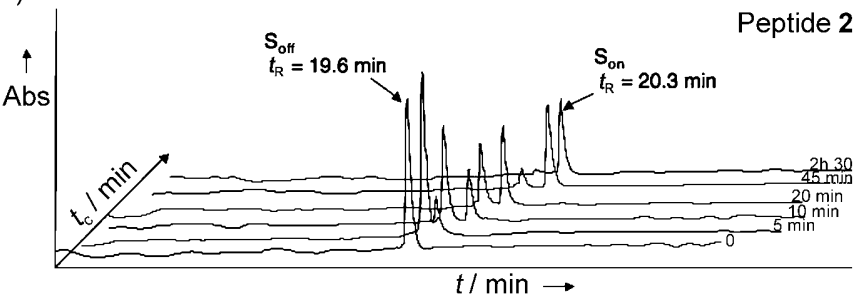

Figure 3. HPLC chromatograms illustrating the kinetics of the acyl migration of peptides 1 and 2 at $400 \mu \mathrm{M}$. HPLC chromatogram of the A) enzymatic cleavage of the dipeptide $\mathrm{H}$-Arg-Pro-OH from peptide 1 ( $\mathrm{S}_{\text {off }}$ state) and the subsequent acyl migration that restores the regular amide backbone $\left(\mathrm{S}_{\text {on }}\right.$ state) and $\mathrm{B}$ ) of the $\mathrm{O}, \mathrm{N}$-acyl migration of peptide 2 at $\mathrm{pH}$ 7.4. $t_{\mathrm{c}}=$ conversion time. These experiments were carried out by using a Vydac Nucleosil 218 TP54 $\mathrm{C}_{18}$ column $250 \times 4.6 \mathrm{~mm}$. At concentrations below $400 \mu \mathrm{m}$ it was not possible to detect the peak transitions by using this column. points to fast aggregation; this originates from the random coil to $\beta$-sheet transition and amyloid formation at the concentrations used for the HPLC studies $(400 \mu \mathrm{M})$. In an attempt to unlink the two processes of acyl migration and fibrillization and facilitate the characterization of amyloid formation by peptides 1 and 2, we monitored the extent of acyl migration and initiation of $\beta$-sheet formation by CD spectroscopy as a function of time at lower peptide concentrations, that is, 20 and $40 \mu \mathrm{M}$ for peptides 1 and 2, respectively.

Enzymatic triggering of peptide $1(20 \mu \mathrm{M})$ results in a gradual transition from random coil in the $S_{\text {off }}$ state, to a predominantly $\beta$-sheet structure in the $S_{\text {on }}$ state as demonstrated by circular dichroism spectroscopy (Figure 4A). This transition appears to go through intermediates that comprise $\alpha$-helical structures, similar to what has been reported for the fulllength $A \beta$ peptides. At $20 \mu \mathrm{M}$ the transition to $\beta$-sheet is complete within 2.5-3.5 h (Figure 4A), as compared to 30-50 min at $50 \mu \mathrm{M}$ (Figure $2 \mathrm{~B}$ ). The extent of amyloid formation in the same samples was monitored by using the Thioflavin T (ThT) fluorescence assay. Figure 4B shows a rapid and significant increase in ThT fluorescence within $2.5 \mathrm{~h}$ of enzymatic triggering and incubation at $37^{\circ} \mathrm{C}$. Only a slight increase in ThT was observed within the next $3 \mathrm{~h}$, and no further change in ThT fluo-
$A \beta$

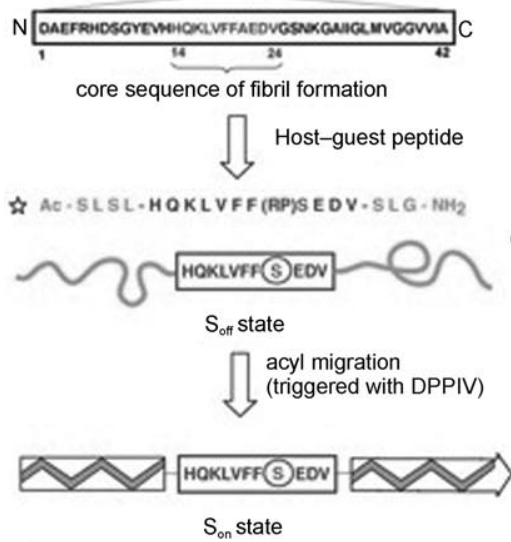

A)

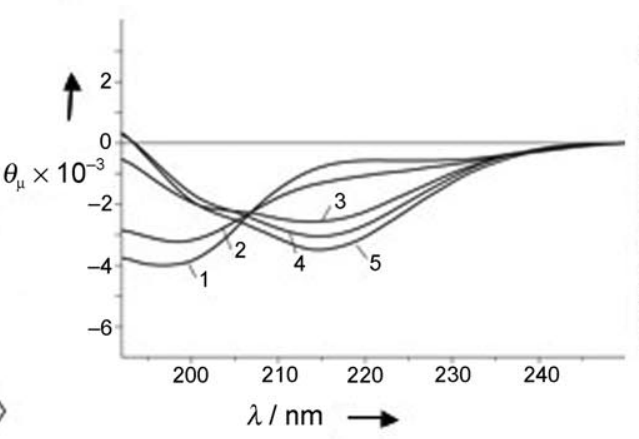

B)

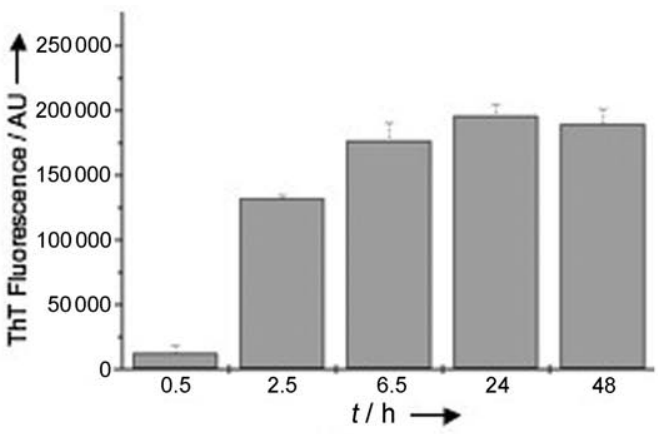

C)
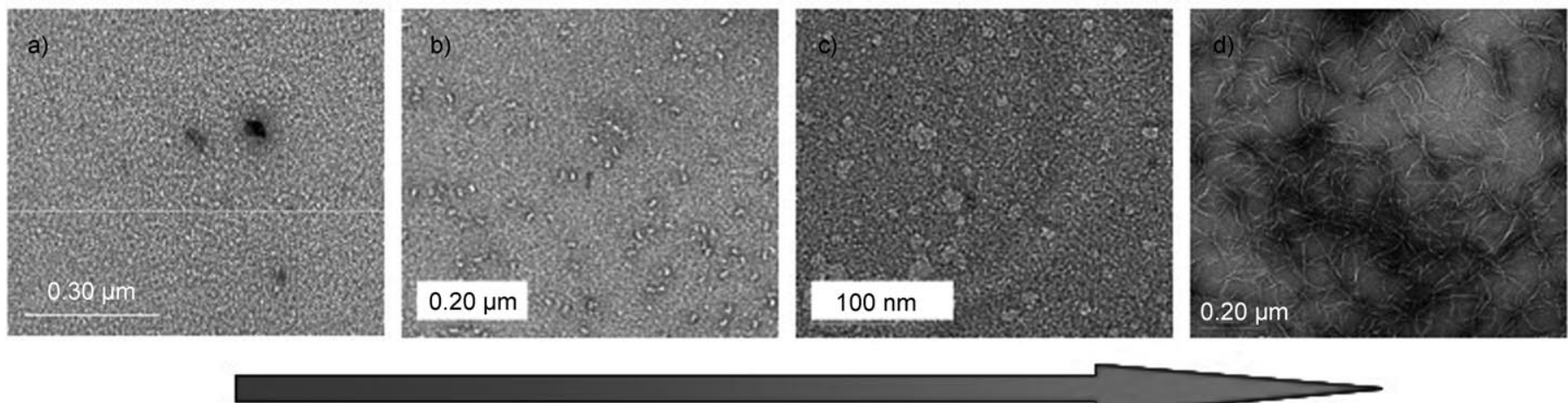

Figure 4. Characterization of acyl migration and amyloid formation of peptide 1 . A) CD spectra of peptide 1 (20 $\mu \mathrm{M}$, Tris buffer (500 $\mu \mathrm{M})+10 \%$ MeOH and $2.5 \mathrm{~mm} \mathrm{NaCl}$ ) before and after DPPIV-induced acyl migration showing the transition from a random coil to a $\beta$-sheet conformation over time (Curves $1, t=$ $0 \mathrm{~h} ; 2, t=1 \mathrm{~h} ; 3, t=1 \mathrm{~h} 45 \mathrm{~min} ; 4, t=3 \mathrm{~h} ; 5, t=6 \mathrm{~h}$ ). B) The extent of amyloid fibril formation of peptide 1 (20 $\mu \mathrm{M})$ as determined by monitoring the increase in ThT fluorescence over time at $37^{\circ} \mathrm{C}$. C) Negatively stained TEM images of peptide 1 in the absence of DPPIV and during the first hour after triggering the acyl migration upon addition of DPPIV; a) $S_{\text {off }}$ state; b) +DPPIV; c) $S_{\text {on }}(t=15 \mathrm{~min})$; d) $S_{\text {on }}(t=2 \mathrm{~h})$ 
rescence occurred after prolonged incubation of up to $42 \mathrm{~h}$; this suggests that amyloid formation of peptide 1 is complete or reaches the maximum within the first 3-6 h. In the absence of DPPIV, electron microscopy studies (Figure $4 \mathrm{C}$ ) revealed that peptide 1 does not undergo aggregation, which is consistent with the $C D$ data (Figure $4 A$ ). This is expected, given the location of the switch in the middle of the $A \beta$-derived hydrophobic peptide $A \beta(14-24)$ (Figure 4). Upon addition of the enzyme, we observe a rapid conversion to predominantly fibrillar structures within the first $2.5 \mathrm{~h}$ of incubation at $37^{\circ} \mathrm{C}$ (Figure $4 \mathrm{C}$ ). Interestingly, TEM images of samples that were taken within the first 5-30 min of incubation demonstrate that amyloid formation by peptide 1 proceeds through aggregation intermediates that bear a striking resemblance to those that were observed during the fibrillogenesis of the full-length $A \beta$ peptides. $^{[19]}$

In the case of peptide $2(40 \mu \mathrm{M})$, the transition from r.c. $\rightarrow \beta$ sheet was complete within the first $4 \mathrm{~h}$ after inducing the acyl migration by adjusting the $\mathrm{pH}$ of the buffer solution to 7.4 (Figure $5 \mathrm{~A}$ ). Although the kinetics of r.c. $\rightarrow \beta$-sheet transition was similar to that observed for peptide 1, formation of amyloid fibrils as determined by ThT binding was significantly slower and reached a maximum value only after $24 \mathrm{~h}$ of incubation at $37^{\circ} \mathrm{C}$ (Figure 5B). Interestingly, peptide 2 seems to form significantly more nonfibrillar aggregates even at a lower concentration than peptide 1 . This observation could be explained by the absence of disrupting elements (switches) within the $A \beta$ sequence to interfere with its self-assembly, and is consistent with the expected role of the flanking host sequences ((Leu-Ser) ${ }_{n}$ oligomers) in promoting $\beta$-sheet formation and fibrillogenesis by $A \beta(14-24){ }^{[18]}$ The high propensity of peptide 2 to form nonfibrillar aggregates could also explain its slow fibrillization kinetics. Early association, which is driven by $A \beta(14-24)$ might direct the aggregation of peptide 2 into nonfibrillar off-pathway aggregates that are then trapped and slowly converted to the normal pathway after induction of acyl migration.

\section{Screening for modulators of fibrillization by using peptides 1 and 2}

To evaluate the potential of host-guest switch-peptides as tools to identify modulators of $A \beta$ aggregation and toxicity, we tested several small molecules that were previously reported to inhibit the fibrillization of the full-length $A \beta$ peptides for their ability to modulate the aggregation of peptides 1 and $\mathbf{2}$ in vitro. Polyphenols such as tannic acid (TA) and myricetin $(\mathrm{Myr}),{ }^{[20]}$ as well as the neurotransmitter dopamine $(\mathrm{DA}){ }^{[21]}$
A)

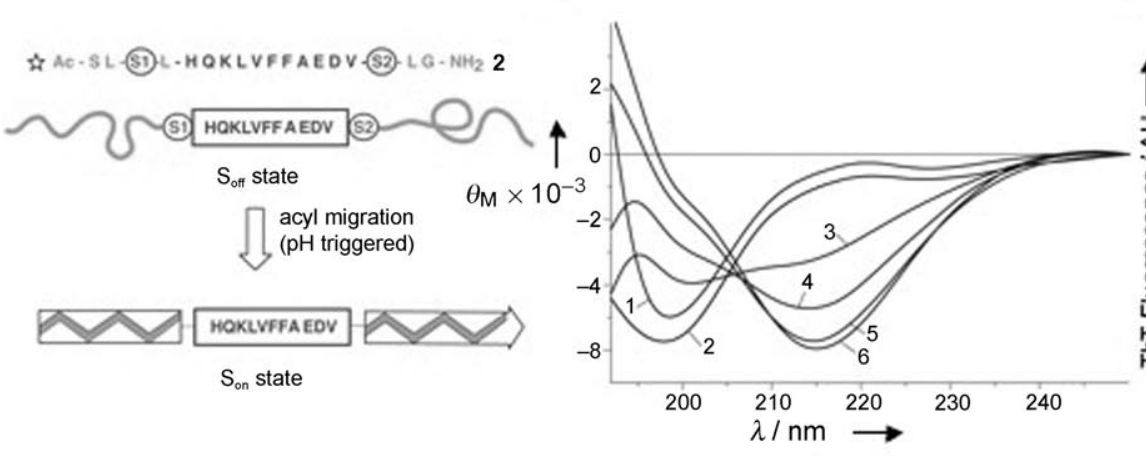

C)
B)

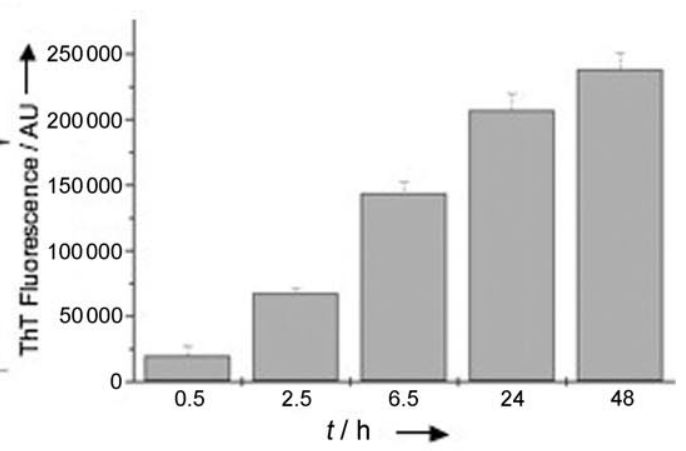

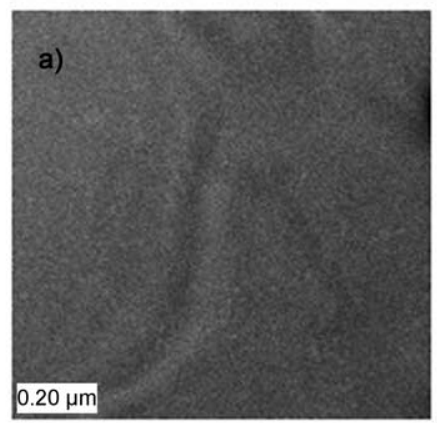
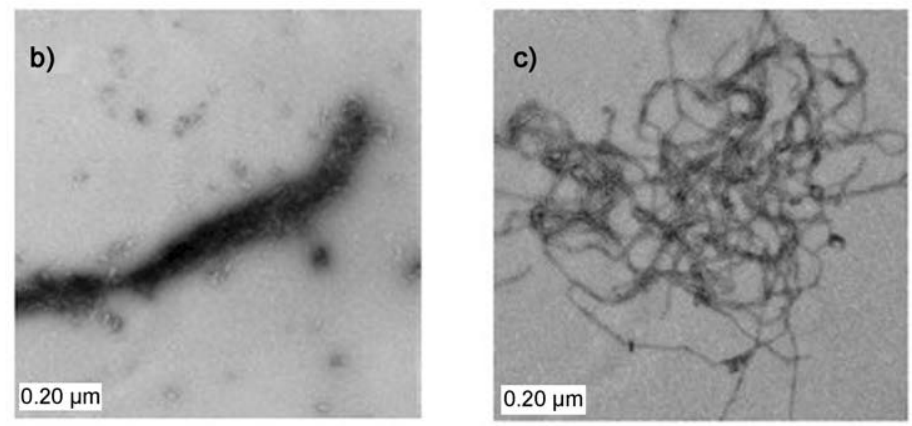

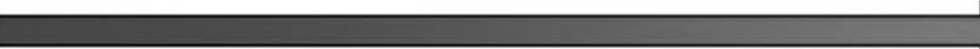

Figure 5. Characterization of acyl migration and amyloid formation of peptide 2 . A) CD spectra of peptide 2 (40 $\mu \mathrm{m}$ ) before and after induction of acyl migration showing the transition from a random coil to a $\beta$-sheet conformation over time (Curves $1, t=0 \mathrm{~h} ; 2, t=1 \mathrm{~h} ; 3, t=2 \mathrm{~h} ; 4, t=3 \mathrm{~h} ; 5, t=4 \mathrm{~h} ; 6, t=6 \mathrm{~h}$ ). B) The extent of amyloid fibril formation of peptide $2(40 \mu \mathrm{m})$ as determined by monitoring the increase in ThT fluorescence over time at $37^{\circ} \mathrm{C}$. C) Negatively stained TEM images of peptide 2 prior to and after the induction of acyl migration by adjusting the $\mathrm{pH}$ to 7.0 (see text); a) $\left.\left.\mathrm{S}_{\text {off }}(t=0) ; b\right) \mathrm{S}_{\text {on }}(t=10 \mathrm{~min}) ; \mathrm{c}\right) \mathrm{S}_{\text {on }}$ $(t=4 \mathrm{~h}$ and $30 \mathrm{~min})$ 
have recently been demonstrated to inhibit $A \beta$ aggregation and/or disrupt preformed $A \beta$ fibrils. ${ }^{[21,22]}$ For this purpose, peptide 1 was dissolved to a final peptide concentration of $20 \mu \mathrm{M}$ in buffer $(500 \mu \mathrm{M}$ Tris $/ 2.5 \mathrm{~mm} \mathrm{NaCl}, \mathrm{pH} 8.0)$ and two to four equivalents of TA, Myr or DA were added to the peptide (in the $S_{\text {off }}$ state) solution. Following the addition of DPPIV, samples were incubated at $37^{\circ} \mathrm{C}$ for $48 \mathrm{~h}$ and amyloid fibril formation was monitored at different time points of incubation by using ThT fluorescence spectroscopy and TEM.

In the absence of the compounds, peptides 1 and 2 (20$40 \mu \mathrm{M}$ ) form amyloid fibrils within the first $5 \mathrm{~h}$ of triggering acyl migration. In the case of peptide 1, maximum ThT fluorescence was reached after $\sim 6 \mathrm{~h}$ of incubation, whereas the ThT fluorescence of peptide 2 continued to increase after $6 \mathrm{~h}$, which is consistent with the data that is shown above (Figures $4 B$ and $5 B$ ). Amyloid formation by peptide 1 was significantly reduced in the presence of TA $(40 \mu \mathrm{M})$ and Myr $(40 \mu \mathrm{M})$. TEM revealed strong inhibition of fibrillogenesis in samples that were coincubated with the polyphenols tannic acid (Figure 6D) or myricetin (Figure $6 \mathrm{E}$ ), as evident by the presence of predominantly protofibrillar species. Previous studies have shown that autooxidation of dopamine is essential for its inhibition of $A \beta 40$ and $A \beta 42$ fibrillization. ${ }^{[21-24]}$ Figure 6 demonstrates that only oxidized dopamine showed strong inhibition of amyloid formation by peptides 1 and 2; this suggests that dopaminerelated inhibition of $A \beta$ fibrillization might be mediated by in- teractions between its oxidation products and the region that comprises residues 14-24. By using RP-HPLC and mass spectrometry we were able to exclude the possibility that the inhibitory effect of the compounds is due to their interference with acyl migration (data not shown).

\section{Discussion and Conclusions}

In this work we describe a novel approach of host-guest switch-peptides that are model systems for amyloid formation; this allows for the study of fibrillogenesis and most importantly, for rapid screening of inhibitors of amyloid formation in vitro. By applying the host-guest concept, combined with the introduction of molecular switches into a fibril-forming sequence that is derived from $A \beta$ ( $A \beta$ 14-24), we were able to design model peptide systems (peptides 1 and 2) that can be triggered to undergo conformational transitions (from random coil to $\beta$-sheet structures) and form amyloid fibrils within a time scale of minutes to hours in a highly controllable and reproducible manner. For example, amyloid formation by peptide 1 is complete within $30 \mathrm{~min}$ to $6 \mathrm{~h}$, depending on the peptide concentration, as opposed to 24 or $48 \mathrm{~h}$ for $\mathrm{A} \beta 42$, and A $\beta 40$ respectively. At lower concentrations $(20 \mu \mathrm{M}$, peptide 1 and $40 \mu \mathrm{M}$ peptide 2 ), random coil to $\beta$-sheet transitions occur only after the conversion from the $\mathrm{S}_{\text {off }}$ to the $\mathrm{S}_{\text {on }}$ state is completed. To our knowledge, these peptides are the first exam-
A)

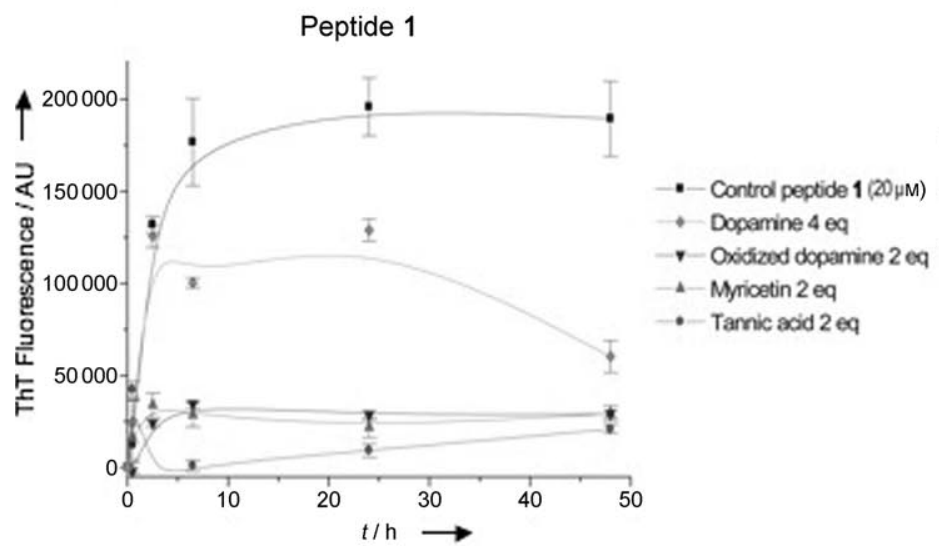

B)

Peptide 2

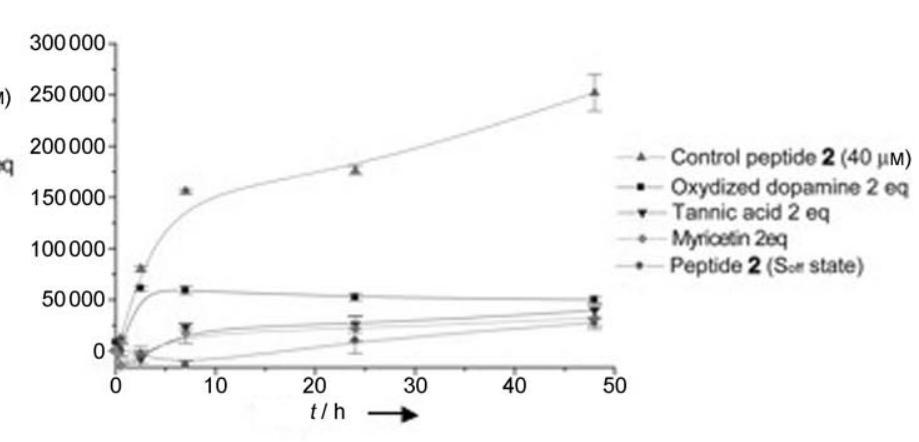

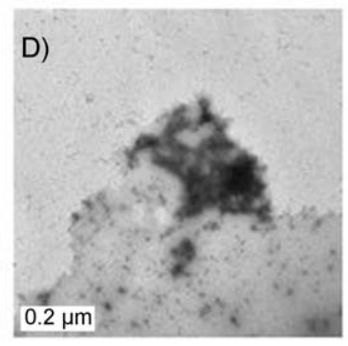
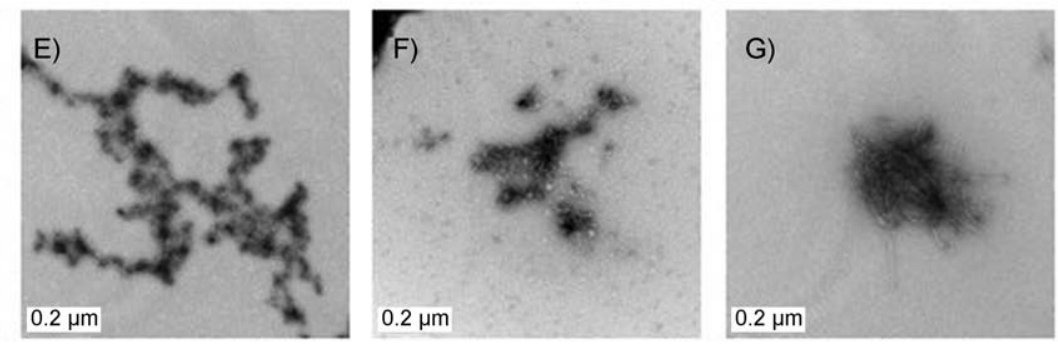

Figure 6. Known inhibitors of full-length $A \beta$ peptides also inhibit the fibrillization of peptides 1 and 2 . ThT fluorescence depicting the extent of amyloid formation of A) peptide $\mathbf{1}$ and B) peptide $\mathbf{2}$ in the absence and presence of known inhibitors of full-length $A \beta$ as a function of time. Peptides $\mathbf{1}$ and $\mathbf{2}$ were dissolved to a final peptide concentration of 20 and $40 \mu \mathrm{m}$ respectively in the presence of two or four equivalents of a potential fibril-destabilizing molecule. Triggering of the switches and hence aggregation of peptides $\mathbf{1}$ and $\mathbf{2}$ was achieved by adding the enzyme DPPIV (peptide $\mathbf{1}$ ) or $10 \%$ of PBS buffer pH 7.4 $\left(300 \mathrm{mM}+150 \mathrm{mM} \mathrm{NaCl}\right.$; peptide 2), followed by an incubation at $37^{\circ} \mathrm{C}$ for $48 \mathrm{~h}$. Negatively stained EM images of peptide 2 at pH 7.4 after $48 \mathrm{~h}$ at $37^{\circ} \mathrm{C}$ : C) $\mathrm{S}_{\text {on }}$ state, control; in the presence of 2 equiv of D) tannic acid, E) myricetin, F) oxidized dopamine, G) peptide $\mathbf{2}$ in the $\mathrm{S}_{\text {off }}$ state, control. 
ples of super-amyloid-forming peptides in which fibrillization can be triggered in a highly controllable manner and is complete within 2-5 $\mathrm{h}$ without the use of any chemical additives or mechanical manipulations to accelerate amyloid formation. Both peptides 1 and $\mathbf{2}$ are easy to synthesize and form aggregation intermediates and amyloid-like fibrillar structures that are similar to those that are formed by the full-length $A \beta$ peptides (Figures 4 and 5). These properties, combined with the fact that the fibrillization kinetics of both peptides is tuneable by manipulating solution conditions (for example, peptide concentration and $\mathrm{pH}$ ) make these host-guest switch-peptides ideal model systems for investigating the structural and molecular mechanisms that underlie amyloid formation in vitro.

Amyloid-forming proteins, including $A \beta, \alpha$-synuclein ( $\alpha$ syn), ${ }^{[25]}$ which is associated with Parkinson's disease, islet amyloid polypeptide peptide (IAPP), which forms pancreatic amyloid deposits in type II diabetes, and the prion protein (PrP) ${ }_{1}^{[26]}$ which is linked to prion diseases possess hydrophobic and highly amyloidogenic sequences in their core structure. These amyloidogenic sequences (for example, NAC region in $\alpha$-syn, SNNFGAILSS in IAPP, FNNGNCFIL in gelsolin, ${ }^{[27]}$ the AGAAAAGA repeat in the prion protein $\left.(\operatorname{PrP})^{[28]}\right)$ which have been shown to be crucial in initiating and/or driving the fibrillization of these proteins. Although several studies have reported small peptide-based inhibitors that are designed to target these regions within full-length $A \beta^{[29,30,31]} \operatorname{IAPP}^{[32,33]}$ and $\alpha$-syn, ${ }^{[34]}$ the hydrophobicity and reduced solubility of these sequences have precluded efforts to use them in high-throughput screening aggregation assays.

To evaluate the potential of applying the host-guest switchpeptide approach to screen for modulators of $A \beta$ aggregation, we tested several small molecules that have been reported to inhibit the fibrillization of $A \beta$ against peptides $\mathbf{1}$ and 2 . Figure 6 demonstrates that inhibitors of $A \beta 40$ and $A \beta 42$ fibrillization also inhibit the aggregation of both peptides $\mathbf{1}$ and 2; this suggests that these molecules might exert their inhibitory effects through interactions with amino acid residues of the core region $A \beta(14-24)$. Our studies support the notion that identifying small molecules that target this region represent a viable strategy for identifying aggregation inhibitors of the full-length proteins. In cases where the conformation of these amyloidogenic regions is dependent on the flanking sequences, it is possible that effective fibrillization inhibitors of the fragment peptides might not be effective against the fulllength proteins. Extending the approach that is described here to other amyloid proteins such as $\alpha$-syn, PrP, and IAPP should facilitate the discovery of small-molecule aggregation inhibitors of these proteins, and might contribute to the development of more efficacious anti-amyloid agents to treat and/or reverse the pathogenesis of neurodegenerative and systemic amyloid diseases.

\section{Experimental Section}

Solid-phase peptide synthesis: The amyloid-derived hostguest switch peptides 1 and $\mathbf{2}$ were prepared by stepwise solid-phase synthesis (SPPS) by using 9-fluorenylmethoxycar- bonyl (Fmoc)/tBu protection and Rink amide resin ${ }^{[35]}$ (Figure S1 in the Supporting Information) that was preswollen with $\mathrm{CH}_{2} \mathrm{Cl}_{2}$ for $30 \mathrm{~min}$. Standard amide couplings were performed by dissolving the Fmoc-protected amino acid (2.5 equiv) with equimolar amounts of benzotriazol-1-yl-oxytripyrrolidinophosphonium hexafluorophosphate (PyBOP) in DMF and stirring for $5 \mathrm{~min}$. The preactivated mixture was added to the resin that was swollen in $\mathrm{CH}_{2} \mathrm{Cl}_{2}$, together with an equimolar amount of $i \mathrm{Pr}_{2} \mathrm{EtN}$. Coupling times were in the range of 30-90 min and the completeness of coupling was verified by the Kaiser test and repeated if necessary. For Fmoc cleavage, the peptide-coupled resin was treated with a $20 \%$ solution of piperidine in DMF $(2 \times 10 \mathrm{~min})$ and then washed with DMF $(3 \times)$ and $\mathrm{CH}_{2} \mathrm{Cl}_{2}$ $(3 \times)$.

In both peptides the switch elements were constructed by first coupling Fmoc-Ser-OH without side-chain protection, and then coupling the next amino acid via an ester bond to the free hydroxyl group of Ser with diisopropylcarbodiimide (DIC) (3 equiv) and 4- $\mathrm{N}, \mathrm{N}$-dimethylaminopyridine ( 0.5 equiv).

Resin cleavage: The peptide resin was treated with a solution of trifluroracetic acid (TFA)/triisopropylsaline (TIS)/ $\mathrm{H}_{2} \mathrm{O} / 3,6$-dioxaoctane-1,8-dithiol (DODT; 95:2:2:1) $2 \times 1 \mathrm{~h}$. Following evaporation of bulk TFA with a stream of dry $\mathrm{N}_{2}$, the peptide was precipitated by the addition of cold diethyl ether, collected by filtration, and washed repeatedly with cold diethyl ether. After cleavage from the resin, peptides 1 and 2 were purified by semipreparative $\operatorname{HPLC}\left(C_{8}, 0\right.$ to $60 \% A, 30 \mathrm{~min}$, peptide 1$)$ and $\left(C_{8}, 30\right.$ to $50 \% A, 30 \mathrm{~min}$, peptide 2$)$, which afforded the desired peptides as a white powder with $>95 \%$ purity (peptide 1: $220 \mathrm{mg}, 30 \%)$ MALDI-TOF MS: $\mathrm{m} / \mathrm{z}$ calcd for $\mathrm{C}_{105} \mathrm{H}_{166} \mathrm{~N}_{28} \mathrm{O}_{30}$ : 2299; found: $2300[\mathrm{M}+\mathrm{H}]^{+}$; HPLC: $t_{\mathrm{R}}=16.4\left(\mathrm{C}_{18}, 0\right.$ to $30 \% \mathrm{~A}$ in $30 \mathrm{~min}$ ) (peptide 2: $500 \mathrm{mg}, 36 \%) \mathrm{ESI}-\mathrm{MS}: \mathrm{m} / \mathrm{z}$ calcd for $\mathrm{C}_{94} \mathrm{H}_{147} \mathrm{~N}_{23} \mathrm{O}_{27}: 2031$; found: $1016.84[(M+2 \mathrm{H}) / 2]^{+}, 678.30$ $[(M+3 \mathrm{H}) / 3]^{+}, 508.78[(M+4 \mathrm{H}) / 4]^{+}, \mathrm{HPLC}: t_{\mathrm{R}}=16.7\left(\mathrm{C}_{18}, 0\right.$ to $30 \% \mathrm{~A}$ in $30 \mathrm{~min}$; Figure $\mathrm{S} 2$ ).

Fibrillization assays: Peptide 1 was dissolved in $\mathrm{MeOH} / \mathrm{H}_{2} \mathrm{O}$ (1:1) to a final concentration of $400 \mu \mathrm{M}$ (stock solution). The solution was vortexed for $30 \mathrm{~s}$ and filtered through a $0.2 \mu \mathrm{m}$ filter by centrifugation for $5 \mathrm{~min}$ at $10000 \mathrm{rpm}$. Aliquots $(50 \mu \mathrm{L})$ of the filtrate were transferred into autoclaved Eppendorf tubes. Tris buffer $(850 \mu \mathrm{L}) \mathrm{pH} 8(500 \mu \mathrm{M}+2.5 \mathrm{~mm} \mathrm{NaCl})$ and $\mathrm{MeOH}$ $(100 \mu \mathrm{L})$ were added to each tube. The inhibitors were dissolved in $\mathrm{MeOH}$ at concentrations of 400 to $800 \mu \mathrm{M}$ and $100 \mu \mathrm{L}$ of these stock solutions were added to the mixture to give the correct final concentration of inhibitor in the reaction mixture. Subsequently, DPPIV enzyme ( $1.5 \mu \mathrm{L}, 0.002$ unit) was added to each sample, and the vials were placed in a water bath at $37^{\circ} \mathrm{C}$ for $48 \mathrm{~h}$. Aliquots $(160 \mu \mathrm{L})$ were removed from the incubated samples at different time points and stored at $-18^{\circ} \mathrm{C}$ until further analysis.

Peptide 2 was dissolved in $\mathrm{H}_{2} \mathrm{O}$ to a final concentration of $800 \mu \mathrm{M}$ (stock solution). The solution was vortexed for $30 \mathrm{~s}$ and filtered through a $0.2 \mu \mathrm{m}$ filter by centrifugation $(5 \mathrm{~min}$ at $10000 \mathrm{rpm})$. Aliquots $(50 \mu \mathrm{L})$ of the filtrate were filled in autoclaved Eppendorf tubes. Acetate buffer $(750 \mu \mathrm{L}, 100 \mu \mathrm{M}$, 
$\mathrm{pH}$ 4.6) was added to each tube. The inhibitors were dissolved in $\mathrm{MeOH}$ at concentrations of $400-800 \mu \mathrm{m}$ and $100 \mu \mathrm{L}$ of these stock solutions were added to the mixture to give the correct final concentration of inhibitor in the reaction mixture. Tris buffer $(100 \mu \mathrm{L}) \mathrm{pH} 7.4(0.3 \mathrm{M}+150 \mathrm{~mm} \mathrm{NaCl})$ was added to each sample to trigger the acyl migration, and the vials were placed at $37^{\circ} \mathrm{C}$ for $48 \mathrm{~h}$. Aliquots $(90 \mu \mathrm{L})$ were removed from the incubated samples at different time points and stored at $-18^{\circ} \mathrm{C}$ until further analysis.

Analytical RP-HPLC: HPLC spectra were recorded on a Waters apparatus that consisted of two Waters 600 pumps, a Waters 600 system controller and a Waters 486 tunable absorbance detector. Vydac Nucleosil $C_{18} 218 T$ TP5 columns $(250 \times$ $4.6 \mathrm{~mm}$ ) and Vydac Nucleosil $C_{8}$ 208TP54 columns (250X $4.6 \mathrm{~mm}$ ) were used with a flow rate of $1 \mathrm{~mL} \mathrm{~min}^{-1}$ and Waters Atlantis dC18 columns $(20 \times 4.6 \mathrm{~mm})$ with a flow rate of $1.5 \mathrm{~mL} \mathrm{~min}^{-1}$. All gradients were linear in eluent A $(0.09 \%$ TFA in $90 \%$ aq acetonitrile) and eluent B (0.09\% TFA in water).

Semipreparative HPLC: Semipreparative purifications were performed on a Waters Delta Prep 3000 system, with a Waters $600 \mathrm{E}$ system controller and a Waters 484 absorbance detector on a Vydac $C_{18} 218 T P 1$ column $(250 \times 21 \mathrm{~mm})$ with a flow rate of $18 \mathrm{~mL} \mathrm{~min}^{-1}$ and UV detection at $214 \mathrm{~nm}$ (eluents and gradients as used for analytical HPLC).

Circular dichroism (CD): CD spectra were recorded on a Jasco J-810 spectropolarimeter that was calibrated with D-(+)-10camphorsulfonic acid. All measurements (in triplicates) were scanned between 190 and $250 \mathrm{~nm}$ with an integration time of $2 \mathrm{~s}$ for $0.2 \mathrm{~nm}$ steps by using quartz cells of $1 \mathrm{~mm}$ path length. Solvent spectra were recorded under the same conditions and were baseline subtracted. Ellipticities were depicted as mean residue ellipticities $(\Theta)$ in $\operatorname{deg} \mathrm{cm}^{2} \mathrm{~mol}^{-1}$.

Electron microscopy (EM): For EM studies the peptide solutions were deposited on to glow-discharged, carbon-coated copper grids. Grids were washed with two drops of $\mathrm{H}_{2} \mathrm{O}$ and stained with two drops of freshly prepared $0.75 \%(w / v)$ uranyl acetate (Electron Microscopy Sciences, Hatfield, PA, USA). Specimens were inspected under a Philips CIME 12 electron microscope, that was operated at $80 \mathrm{kV}$. Digitized photographs were recorded with a slow scan CCD camera (Model 679, Gatan, CA, USA).

Thioflavin T fluorescence assay (ThT): Fibril formation was monitored by the thioflavin T (ThT) (Sigma) fluorescence assay. Readings were carried out at a final protein and ThT concentration of $10 \mu \mathrm{M}$ in a final volume of $100 \mu \mathrm{L}$ of $50 \mathrm{~mm}$ glycine$\mathrm{NaOH}$ buffer ( $\mathrm{pH}$ 8.5). ThT fluorescence measurements were recorded on an analyst fluorescence instrument (LJL Biosystems, Sunnyvale (A, USA) at an excitation and emission wavelength of $450 \mathrm{~nm}$ and $485 \mathrm{~nm}$, respectively. The relative fluorescence at $485 \mathrm{~nm}$ was used as a measure of the amount of fibrillar aggregates that were formed in solution, and was corrected by the fluorescence level of the peptide at time 0 . All samples were analysed in triplicates and the data were plotted by using Microcal Origin.

\section{Acknowledgements}

This work was supported by grants from the Swiss National Science Foundation (H.A.L., M.M. and M.-S.C.) and Debiopharm SA, Lausanne. We thank Prof. Jacques Dubochet, Laboratoire d'Analyse Ultrastructurelle, University of Lausanne, for granting us access to the electron microscopy facility.

Keywords: aggregation - Alzheimer's disease - amyloid fibrils conformation analysis $\cdot$ host-guest switch peptides

[1] M. Stefani, C. M. Dobson, J. Mol. Med. 2003, 81, 678-699.

[2] M. P. Mattson, Physiol. Rev. 1997, 77, 1081-1132.

[3] D. M. Walsh, I. Klyubin, J. V. Fadeeva, J. W. Cullen, R. Anwyl, M. S. Wolfe, M. J. Rowan, D. J. Selkoe, Nature 2002, 416, 535-539.

[4] P. T. Lansbury, H. A. Lashuel, Nature 2006, 443, 774-779.

[5] M. Mutter, A. Chandravarkar, C. Boyat, J. Lopez, S. Dos Santos, B. Mandal, R. Mimna, K. Murat, L. Patiny, L. Saucede, G. Tuchscherer, Angew. Chem. 2004, 116, 4267-4273; Angew. Chem. Int. Ed. 2004, 43, 4172-4178.

[6] S. Dos Santos, A. Chandravarkar, B. Mandal, R. Mimna, K. Murat, L. Saucède, P. Tella, G. Tuchscherer, M. Mutter, J. Am. Chem. Soc. 2005, 127, $11888-11889$.

[7] G. Tuchscherer, A. Chandravarkar, M.-S. Camus, J. Bérard, K. Murat, A. Schmid, R. Mimna, H. A. Lashuel, M. Mutter, Biopolymers 2007, 88, 239252.

[8] L. Saucède, S. Dos Santos, A. Chandravarkar, B. Mandal, R. Mimna, K. Murat, M.-S. Camus, J. Bérard, E. Grouzmann, M. Adrian, J. Dubochet, J. Lopez, H. Lashuel, G. Tuchscherer, M. Mutter, Chimia 2006, 60, 199-202.

[9] Y. Sohma, M. Sasaki, Y. Hayashi, T. Kimura, Y. Kiso, Chem. Commun. (Cambridge) 2004, 124-125.

[10] Y. Sohma, Y. Kiso, ChemBioChem 2006, 7, 1549-1557.

[11] L. A. Carpino, E. Krause, C. D. Sferdean, M. Schümann, H. Fabian, M. Bienert, M. Beyermann, Tetrahedron Lett. 2004, 45, 7519-7523.

[12] I. Coin, R. Dölling, E. Krause, M. Bienert, M. Beyermann, C. D. Sferdean, L. A. Carpino, J. Org. Chem. 2006, 71, 6171-6177.

[13] Y. Hamada, J. Ohtake, Y. Sohma, T. Kimura, Y. Hayashi, Y. Kiso, Bioorg. Med. Chem. 2002, 10, 4155-4167.

[14] R. Oliyai, V. J. Stella, Bioorg. Med. Chem. Lett. 1995, 5, 2735-2740.

[15] W. M. Kazmierski, P. Bevans, E. Furfine, A. Spaltenstein, H. Yang, Bioorg. Med. Chem. Lett. 2003, 13, 2523-2526.

[16] I. Coin, P. Schmieder, M. Bienert, M. Beyermann, J. Pept. Sci. 2008, 14, 299-306.

[17] L. O. Tjernberg, D. J. Callaway, A. Tjernberg, S. Hahne, C. Lilliehöök, L. Ternius, J. Thyberg, C. Nordstedt, J. Biol. Chem. 1999, 274, 12619-12625.

[18] M. Mutter, F. Maser, K. H. Altmann, C. Toniolo, G. M. Bonora, Biopolymers 1985, 24, 1057-1074.

[19] H. A. Lashuel, D Hartley, B. P. Wall, M. Simon, T. Walz, P. T. Lansbury, J. Mol. Biol. 2003, 332, 795-808.

[20] K. Ono, K. Hasegawa, H. Naiki, M. Yamada, Biochim. Biophys. Acta Mol. Basis Dis. 2004, 1690, 193-202.

[21] J. Li, M. Zhu, A. B. Manning-Bog, D. A. Di Monte, A. L. Fink, FASEB J. 2004, 18, 962-964.

[22] H. A. Lashuel, D. M. Hartley, D. Balakhaneh, A. Aggarwal, S. Teichberg, D. J. Callaway, J. Biol. Chem. 2002, 277, 42881-42890.

[23] M. Necula, R. Kayed, S. Milton, C. G. Glabe, J. Biol. Chem. 2007, 282, 10311-10324.

[24] K. Ono, Y. Yoshiike, A. Takashima, K. Hasegawa, H. Naiki, M. Yamada, J. Neurochem. 2003, 87, 172-181.

[25] O. M. A. El-Agnaf, A. Bodles, D. J. S. Guthrie, P. Harriott, G. B. Irvine, Eur. J. Biochem. 1998, 258, 157-163.

[26] T. Pillot, L. Lins, M. Goethals, B. Vanloo, J. Baert, J. Vandekerckhove, M. Rosseneu, R. Brasseur, J. Mol. Biol. 1997, 274, 381-393.

[27] P. Westermark, U. Engström, K. H. Johnson, G. T. Westermark, C. Betsholtz, Proc. Natl. Acad. Sci. USA 1990, 87, 5036-5040.

[28] C. P. J. Maury, E.-L. Nurmiaho-Lassila, H. Rossi, Lab. Invest. 1994, 70, 558564.. 
[29] C. Soto, M. S. Kindy, M. Baumann, B. Frangione, Biochem. Biophys. Res. Commun. 1996, 226, 672-680.

[30] C. Soto, E. M. Sigurdsson, L. Morelli, R. A. Kumar, E. M. Castano, B. Frangione, Nat. Med. 1998, 4, 36-40.

[31] L. O. Tjernberg, C. Lilliehöök, D. J. Callaway, J. Näslund, S. Hahne, J. Thy berg, L. Terenius, C. Nordstedt, J. Biol. Chem. 1997, 272, 12601-12605.

[32] L.-M. Yan, M. Tatarek-Nossol, A. Velkova, A. Kazantzis, A. Kapurniotu, Proc. Natl. Acad. Sci. USA 2006, 103, 2046-2051.

[33] M. Tatarek-Nossol, L.-M. Yan, A. Schmauder, K. Tenidis, G. Westermark, A. Kapurniotu, Chem. Biol. 2005, 12, 797-809.
[34] A. M. Bodles, O. M. El-Agnaf, B. Greer, D. J. Guthrie, G. B. Irvine, Neurosci. Lett. 2004, 359, 89-93.

[35] W. C. Chan, P. D. White, Fmoc Solid Phase Peptide Synthesis-A Practical Approach, Oxford University Press, Oxford 2000.

Received: April 11, 2008

Published online on August 5, 2008 